\title{
NUTRIENT VARIABILITY IN MANGROVE SOIL: ANTHROPOGENIC, SEASONAL AND DEPTH VARIATION FACTORS
}

\author{
SOFAWI, A. B. ${ }^{1}-$ NAZRI, M. N. ${ }^{1}-$ ROZAINAH, M. Z. ${ }^{1,{ }^{*}}$ \\ ${ }^{1}$ Institute of Biological Science, Faculty of Science, University of Malaya \\ 50603 Kuala Lumpur, Malaysia \\ (phone: +60-3-7967-4390; fax: +60-3-7967-4178) \\ ${ }^{2}$ Institute of Ocean and Earth Sciences, University of Malaya \\ 50603 Kuala Lumpur, Malaysia \\ (phone: +60-3-7967-6794; fax: +60-3-7967-4178) \\ *Corresponding author \\ e-mail:rozainah@um.edu.my \\ (Received $2^{\text {nd }}$ Jun 2017; accepted 25 ${ }^{\text {th }}$ Oct 2017)
}

\begin{abstract}
The aim of this study is to assess the soil texture and nutrient components across three seasons at three different mangroves habitat according to the land used types; Kelantan (human settlement area); Johor (protected Ramsar's site) and Selangor (agricultural). The soils were sampled one-meter deep and divided into five segments for analysis. The $\mathrm{pH}$ of surface water for Selangor and Kelantan were slightly acidic ranging from 6.4 to 6.9. In Johor, the water was basic with value ranging from 8.3 to 8.7 across all seasons. Salinity in Selangor (26 ppm) was higher than in Johor (16 ppm) and in Kelantan (11 ppm). Johor and Selangor soils were dominated by silty loam, while Kelantan was dominated by sandy loam. Carbon, nitrogen, phosphorus and potassium analysis showed that they were significantly different in all locations but not between seasons. Except for phosphorus in Johor, consecutive depth did not influence the nutrient availability in mangrove soil. The results for carbon and nitrogen were following this order; Johor > Kelantan > Selangor, phosphorus; Selangor > Johor > Kelantan, potassium; Johor $>$ Selangor $>$ Kelantan. The protected mangroves habitat in Johor has siltier and clayey component and can retain more nutrients for the plant growth. Therefore, the conservation and preservation of mangroves habitat is crucial for the stable coastal ecosystems.
\end{abstract}

Keywords: soil texture, carbon, nitrogen, phosphorus, potassium

\section{Introduction}

Mangroves are a diverse group of predominantly trees, shrubs, palms and grounds ferns, which have adapted to the extreme saline conditions between the tides (Duke et al., 2002). They are one of the most productive and unique ecosystems, growing on sheltered shores and in estuaries in the tropical and subtropical area (Hogarth, 2015). Although the number of species diversity is low as compared to terrestrial ecosystems, it is the various adaptation abilities to survive the harsh environment (e.g. strong wind, high salinity and muddy substrate) that makes this ecosystem so critical and crucial for conservation. The largest mangroves areas are located in Asia, extending over 6.8 million ha and representing about 34-42\% of the world's total (Giri et al., 2011). Furthermore, many mangroves species were located at the equatorial area or country such as Indonesia, Malaysia and Philippines (Spalding et al., 2010). This forest is high in values, serves multiple ecological roles and important for socio-economic and microbes continuity (Walters et al., 2008). For instance, the high demand of charcoal and firewood had resulted in high production of mangrove woods in southern region of 
ASEAN, estimated around 10 to 17 tonnes/ha/year (Bosire et al., 2008). In Peninsular Malaysia, fish landing alone has been reported as much as 0.86 million tonnes in 2003 and this number increased every year (Chong, 2007).

Therefore, over the past decades, mangrove ecosystem became a subject to a high pressure of anthropogenic activities and natural phenomenon (Giri et al., 2011; Jusoff, 2013). Reclamation of mangroves area for development purposes; i.e. industrial area, human settlement, port and agriculture has been increasing and such acts have caused irreversible damage in coastal area. Erosion and accretion of the coastline regions are changing the sediment properties, physical and/or chemical ones (Kamaruzzaman et al., 2008). The mangrove forest clearance activities through unsustainability logging decreased the nutrients concentration in soil (Ngole-Jeme et al., 2016). This is due to the lack of litter production in mangroves ecosystems (Hemati et al., 2015). In addition, the climate change has contributed to sea level rise which directly causes the coastline changes and alter the mangrove coverage worldwide. This will change the coastline landscape and mangroves area that could change the soil physical and chemical properties (Tajul Baharuddin et al., 2013).

A good establishment of mangrove stands relies on the soil properties and this has been reported by several authors (e.g. Li et al., 2008; Kamali and Hashim, 2011; Salmo et al., 2013). Soil provides a good source of nutrient for growth and strong physical structure for anchorage and stability being in the soft sediments (Ashman and Puri, 2002). In mangroves, the sediment or soil texture, salinity and $\mathrm{pH}$ are important physical elements in determining the condition of the study area. The ability of soils to retain $\mathrm{C}$, water and nutrient ions are strongly influenced by the soil texture (Havlin et al., 2014). Basically, soil texture is determined through the particle size percentage of clay, silt and sand (Ashman and Puri, 2002). The mixture of the results in actual mangrove sedimentation is classified as sand, loamy sand, sandy loam, loam, silt loam, silt, silty clay, silty clay loam, clay loam, sandy clay loam, sandy clay and clay. Most of the mangrove soils are known as mud, which is the mixture of silt and clay (Spalding et al., 2010).

The study on soil texture is important as mangrove plants may grow in different types of soil, hence determining the mangroves zonation pattern (Vilarrubia, 2000; Sherman et al., 2003; Twilley and Day, 2012). The soil pores are different for clay, silt and sand. For clay, the soil pores are the smallest when compared to silt and sand. Hence, this type of soil has a higher ability to retain water and nutrients (Ashman and Puri, 2002). Sasternegara (2004) reported that the silty clay is mostly found at the mangroves area, either logged or undisturbed mangroves area. But some species may favor other types of soil. Avicennia sp. can be found at the seaward zone with sandy soil type (Lewis, 2005; Ibrahim and Hussain, 2012). While for other species like Rhizophora spp. and Bruguiera spp. are mostly found in silty clay area (Robertson and Alongi, 1992; Ibrahim and Hussain, 2012).

Apart from soil texture, $\mathrm{pH}$ and salinity also play an important role in mangrove distribution. Several studies of mangrove forests worldwide had found that mangrove soil may be either acidic or alkaline (Wakushima et al., 1994; Salmo et al., 2014; Hemati et al., 2015). In the Sibuti Wildlife Santuary Miri, Sarawak, the $\mathrm{pH}$ was acidic with average 3.34 in the area dominated with Rhizophora apiculata (Rambok et al., 2010). In Sundarban forests, the $\mathrm{pH}$ values were slightly alkaline ranging from 7.4 to 8.2 with various mangroves species (Das et al., 2012). For the salinity, there are a few species known as halophilic or salt tolerant (Nandy et al., 2007). Salinity may affect the structure of mangrove forests through the distribution of dominant species in Gazi Bay 
(Matthijs et al., 1999). Mangroves species that face tidal inundation daily or twice a month may tolerate extreme $\mathrm{pH}$ and high salinity (Nandy et al., 2007). But, Wakushima et al. (1994) stated clearly that the $\mathrm{pH}$ and salinity were highly affecting the zonal distribution of mangroves. Kandelia candel is the species that can grow well in low pH and salinity, while Avicennia sp., Rhizophora sp. and Sonneratia sp. can tolerate extreme $\mathrm{pH}$ and high salinity (Wakushima et al., 1994).

In term of soil chemical or nutrient properties, mangroves areas are also subjected to the changes of chemical concentrations, either in soil or water. Yet, the study about this matter is limited. Mangals are finely balanced, highly effective nutrient sinks with net imports of dissolved nitrogen, phosphorus and silicon. Nutrient fluxes in these environments are closely tied to particle size, $\mathrm{pH}$ and salinity, water input, plant assimilation and microbial mineralization (Alongi et al., 2013). Varying nutrient concentrations can also change competitive balances and affect species distributions (Chen and Twilley, 1999; Twilley and Chen, 1998). The carbon (C) in soil is determined by organic carbon and the production of $\mathrm{C}$ is depending majorly from litter such as leaf, propagule, seed, trunk and root (Alongi, 2014). The nitrogen $(\mathrm{N})$ is highly present in soil through biological fixation, transformation and leaching (Nandy et al., 2007). Like $\mathrm{C}, \mathrm{N}$ concentration in soil is also originated from the decomposition process of litter and the lack of this element in soil will cause soil infertility (Ashman and Puri, 2002). Phosphorus (P) element in soil is present as phosphate ion and it is required by the plant in large amount for growth (Greger, 2004). Potassium ( $\mathrm{K}-$ known as Kalium) is another element that present in soil in form of cationic (Ashman and Puri, 2002). K is more abundant in silty or clayey soil compared to sand (Reef et al., 2010).

In mangrove forest, the nutrients are supplied by the litter fall from trees and suspended materials from surface runoff above ground, fauna activities and microorganisms' decomposition mechanism (Cannicci et al., 2008). The litter fall or surface materials were utilized by macro invertebrates such as Scylla serrata and that is broken down into smaller sizes. Then, the process was taken over by microorganisms until all the materials deposit into the soil permanently.

Soil physical and chemical properties of mangrove forest can indicate the current status and can determine the characteristics of tested soil (Furukawa and Wolanski, 1996; Havlin et al., 2014). Data obtained may represent the soil status of mangroves area thus to plan a proper action for enhancement of soil quality and governing ideal ecosystem. As medium of growth, soil should supply enough nutrients and have good characteristic to ensure better tree performance and establish greater forest ecosystem for wildlife conservation, economic value and most important to balancing environmental condition (Hopkins and Huner, 2004). According to Gruber and Galloway (2008), changes in land use patterns, coupled with climate issue and rising of global population have given a serious impact on nutrient release into the environment. Soil nutrient status has the most direct controls on the mangrove ecosystems (Alongi et al., 2003). Concentrations of nutrients and organic matter in mangrove soil can also be subjected to anthropogenic activities nearby such as sewage discharge either from and waste dumping (An et al., 2007).

As a result, nutrient availability could threaten ecological balance in mangrove ecosystems. Yet, the study about the effect of soil characteristics is still lacking in mangroves area. Many authors focused on the crop study as the intention to develop agricultural activities is the main concern for many countries (Ashman and Puri, 2002; Havlin et al., 2014). In this paper, we ask this question: to what extent the changes in 
land use pattern can alter the physical and chemical properties in mangrove soil? Hence, we attempt to examine seasonal and depth variation and variability of soil nutrient concentration in three different mangrove forests in Peninsular Malaysia, based on different anthropogenic activities.

\section{Material and methods}

\section{Study site}

In this study, three sites within Peninsular Malaysia were selected based on mangroves forest status and the activities at the surrounding area. The sites chosen are shown in Figure 1. The study was conducted within the Mangrove Forest Reserve (MFR) under the surveillance of Department of Forestry Peninsular Malaysia (DFPM). Generally, three criteria were selected; 1) mangroves at human settlement area (villages) at Kelantan (east coast), 2) mangroves at Ramsar's Site at Johor (southern-west coast) and 3) mangroves at agriculture area at Selangor (west coast).

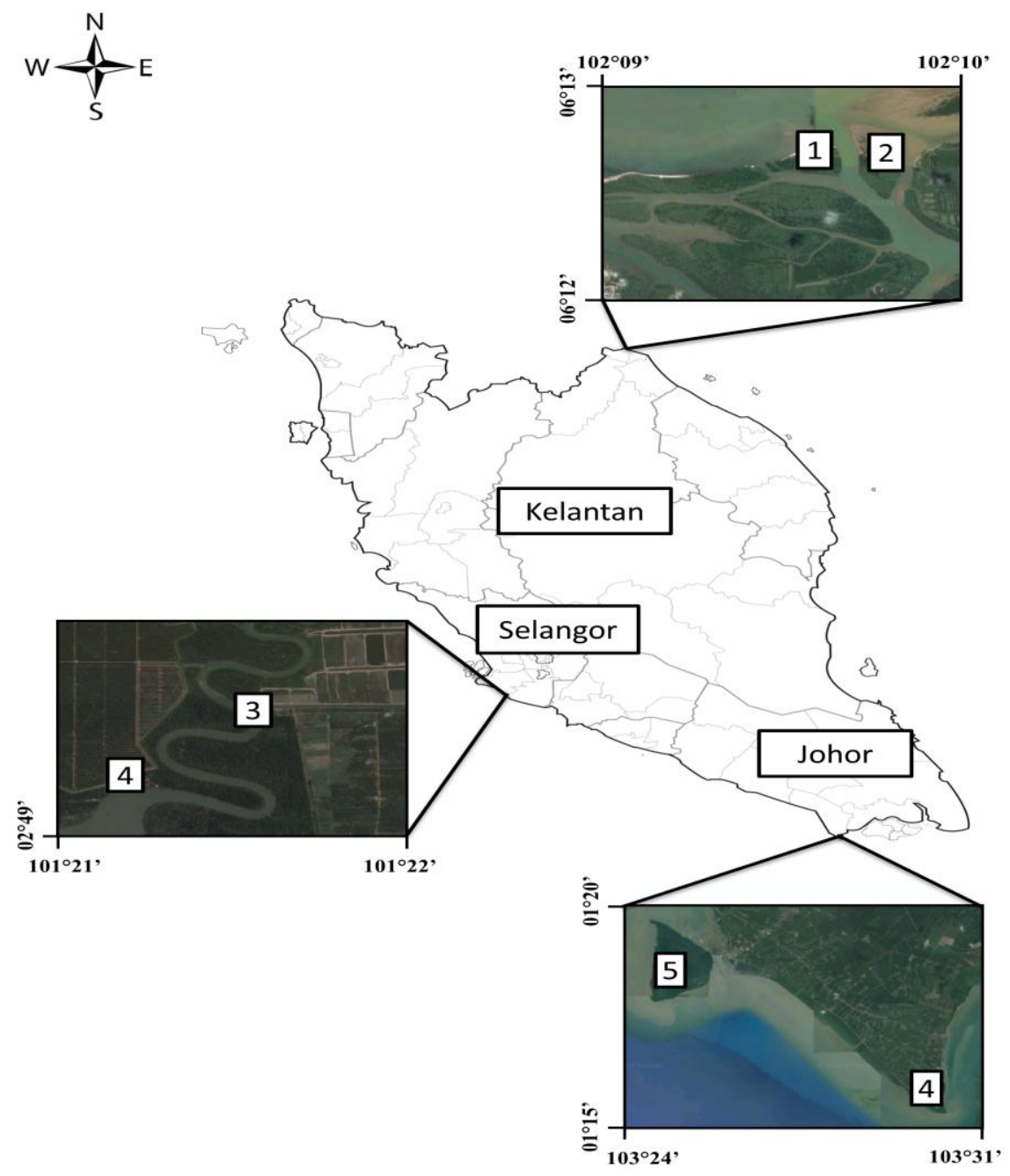

Figure 1. The map of the study site. (1: Pulau Che Minah; 2: Pulau Terendak (both at Delta Kelantan); 3: Kampung Melayu Carey; 4: West Palm Oil Plantation (both at Carey Island); 5: Pulau Kukup; 6: Tanjung Piai (both at Ramsar's Site, Johor) 


\section{Delta Kelantan}

The main river running through the delta is the Kelantan River, which meets the South China Sea at the east of the study area. A large delta has been developed by the river with sand spits and sand bars common at, and close to the outlets of larger river mouth. There are almost seventeen islands surrounding Delta Kelantan where area was covered with mangrove forests around 1200 ha. In this case study, Pulau Terendak

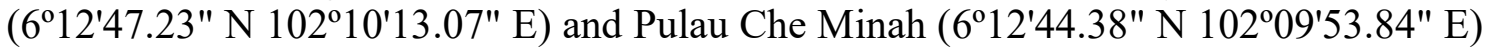
were chosen and both locations were located in the western part of Kelantan Delta, Tumpat. Kelantan state's climate regime is influenced by the northeast and southeast monsoons that blow from late November to March and from June to September respectively. The estimated total amount of rainfall was $2700 \mathrm{~mm}$ per annum with heavy rainfall during the Northeast monsoon (November to March). The temperature ranged from $22.7{ }^{\circ} \mathrm{C}$ to $32.9^{\circ} \mathrm{C}$ with and estimated mean of $26.8^{\circ} \mathrm{C}$. The humidity of the region was estimated to be about $83.7 \%$ (Malaysian Meteorology Department (MMD), 2010a; 2010b). There were few species can be found at Delta Kelantan. But the most common species were Sonneratia caseolaris, Nypa fruticans, Avicennia alba, Rhizophora mucronata and Bruguiera gymnorrhiza (Satyanarayana et al., 2010).

\section{Ramsar sites, Johor}

Johor is the southern states in peninsular Malaysia where also the home of three Ramsar Sites (wetland of Pulau Kukup, Tanjung Piai and Sungai Pulai Forest Reserves). Johor was estimated to hold $28.7 \%$ (27,733 ha) of mangrove forests in Peninsular Malaysia (Wetlands International Malaysia, 2009). In Johor, Pulau Kukup ( $\left.1^{\circ} 18^{\prime} 60.00^{\prime \prime} \mathrm{N} 103^{\circ} 26^{\prime} 59.99^{\prime \prime} \mathrm{E}\right)$, Tanjung Piai (01 $\left.{ }^{\circ} 16^{\prime} 1.177^{\prime \prime N} 103^{\circ} 30^{\prime} 37.766 " \mathrm{E}\right)$ and Sungai Pulai (1²3'39.01" N 103³2'33.3" E) besides being Ramsar Sites are also designated as State National Parks. Pulau Kukup, Tanjung Piai and Sungai Pulai covered about 10,299 ha of mangroves in Johor. Pulau Kukup is a mangrove island while Tanjung Piai and Sungai Pulai are coastal mangrove. In this study, only two from three Ramsar sites were chosen which are Tanjung Piai and Pulau Kukup. According to Tan et al. (2012), Pulau Kukup has the higher number of species with 11 species compared to Tanjung Piai with only 9 species. Pulau Kukup are typical examples of a Rhizophora-Bruguiera dominated coastal forest. It is dominated by Rhizophora apiculata as the most common species, followed by Bruguiera cylindrica and Ceriops tagal, while Rhizophora mucronata is found along channels. The total amount of rainfall in this area was about $2104.1 \mathrm{~mm}$. The highest and the lowest rainfall were in July $(302.9 \mathrm{~mm})$ and April $(84.4 \mathrm{~mm})$, respectively. The air temperature was highly recorded in May with $29.5{ }^{\circ} \mathrm{C}$ and the lowest was in January 2011 of $26.0{ }^{\circ} \mathrm{C}$ (Nordatul Akmar and Wan Juliana, 2012).

\section{Carey Island, Selangor}

Carey Island, Selangor is located approximately $70 \mathrm{~km}$ south from Kuala Lumpur. Carey Island is one of the 8 islets within Klang Isles facing the Straits of Malacca and separated from mainland by Langat River. The total area of Carey Island is 16,187.45 ha comprising of $65 \%$ of palm oil plantation while the rest are divided into forest reserves $(1,876.85 \mathrm{ha})$ and settlements. The study was conducted at Kampung Melayu Carey $\left(02^{\circ} 49^{\prime} 2.2376^{\prime \prime} \mathrm{N} \quad 101^{\circ} 21^{\prime} 16.236 " \mathrm{E}\right)$ and West Palm Oil Plantation $\left(02^{\circ} 49^{\prime} 24.2904^{\prime \prime} \mathrm{N} 101^{\circ} 21^{\prime} 34.65^{\prime \prime E}\right)$. The total annual rainfall is $2,100.5 \mathrm{~mm}$ with the 
maximum and minimum monthly rainfalls were $496.0 \mathrm{~mm}$ and $28.3 \mathrm{~mm}$ in December 2012 and March 2013, respectively. The tide at this area is irregular and semi-diurnal, with two high tides and low tides in one day. An extensive survey in 2008 revealed that there were 43 mangrove species including associate species fringing around Carey Island (Rozainah and Irfan, 2017). Furthermore, Saraswathy et al. (2009) recorded that Avicennia alba, A. officinalis and Rhizophora mucronata are the dominant species here. The zonation patterns of the mangrove trees are obviously dominated by Avicennia sp. and Rhizophora sp. majorly at $5 \mathrm{~m}$ to $20 \mathrm{~m}$ seaward zone.

\section{Soil sampling}

Soil samples at one-meter depth were taken during low tide using a soil sampler (Eijkelkamp multi-sampler) at each location with three replicates. Then, the soil was divided into five segments according to vertical depth (0-20, 20-40, 40-60, 60-80 and 80-100 cm). The soil samples were taken during three different seasons; wet season (October-December), dry season (June-September) and inter-monsoon period (MarchMay) from November 2012 until July 2014 (Malaysian Meteorology Department (MMD), 2010a, 2010b). The soil was kept in sealed plastic bag at $4{ }^{\circ} \mathrm{C}$ and brought back immediately to the laboratory for further analysis. In laboratory, the soil samples were air-dried in room temperature for five days. Then, the soils were sieved through 2$\mathrm{mm}$ screen to remove visible roots, litters and large elements such as shell.

\section{Soil physical (texture) and chemical analysis}

The soil surface water was taken for in-situ salinity test using a refractometer (Master-S10M, Atago Co. Ltd., Tokyo, Japan) and the $\mathrm{pH}$ was tested using a $\mathrm{pH}$ meter (IQ 170, Spectrum Technologies Inc., San Diego, USA). A total of 270 soil samples were sieved into less than $2 \mathrm{~mm}$ and further tested using a Beckman Coulter (LS 13, 320) to determine the soil texture (silt, clay and sand). The results were then calculated by percentage while the soil triangle (USDA, 1951) was used to determine the soil type.

The soil chemical studies were conducted using four nutrient parameters. The organic carbon (C) content was analysed using the Walkley and Black analysis (De Vos et al., $2007)$ and the results were reported in percentage (\%). The total nitrogen (N) analysis was done using Kjedahl method and results for the determination of total nitrogen by distillation process were reported in percentage (\%) (Nelson and Sommers, 1980). Phosphorus (P) analysis was done by determining the available P in soil using the Deniege method and the results were reported in part per million (ppm) (Binkley and Fisher, 2012). The potassium (K) analysis was done using the determination of exchangeable $\mathrm{K}$ by distillation method and the results were reported in $\mathrm{cmol} / \mathrm{kg}$ (Ross, 1995).

\section{Statistical analysis}

All the results from 2 sampling locations in each site were pooled together to represent only one site. Analysis of variance (ANOVA) was performed to compare differences in soil physical and chemical properties between study sites, seasons and vertical depth. Analyses were performed using SPSS (version 20.0), including the assumption tests. Means were compared using the Tukey honest significant difference (HSD) test to evaluate variations in physical and chemical properties with sites and seasons and with sites and depth. 


\section{Results}

\section{Soil physical analysis}

In terms of $\mathrm{pH}$, Selangor and Kelantan showed that the surface water were slightly acidic in wet and intermediate season ranging from 6.4 to 6.9 , while slightly basic in dry season with value $>7$. On the other hand, sites in Johor indicated that the water was in basic condition with value ranging from 8.3 to 8.7 across all seasons. The salinity results were difference for each site, where Selangor study site showed the highest value ranging from $20 \mathrm{ppm}$ to $26 \mathrm{ppm}$, followed by Johor with value of $14 \mathrm{ppm}$ to $16 \mathrm{ppm}$. The salinity at Kelantan was the lowest with the average of $11 \mathrm{ppm}$.

In this study, the soil textures were different for each location. The results showed significant difference amongst sites for all parameters. The composition of clay and silt were recorded high in Johor site while sand composition was highest at Kelantan. But in term of season, there were no significant difference for all locations. At Johor and Selangor study site, the soils were dominated by silty loam type. Whereas, in Kelantan, the soil type was sandy loam type (Table 1).

Table 1. Soil texture at different seasons and locations (mean $\pm S D$ )

\begin{tabular}{|c|c|c|c|c|c|}
\hline Location & Season & Clay (\%) & Silt (\%) & Sand $(\%)$ & Soil type \\
\hline \multirow{4}{*}{ Johor } & Dry & $9.24 \pm 0.65$ & $75.34 \pm 3.46$ & $15.40 \pm 3.69$ & Silt loam \\
\hline & Wet & $10.17 \pm 3.05$ & $74.98 \pm 4.00$ & $14.85 \pm 4.59$ & Silt loam \\
\hline & Intermediate & $9.12 \pm 0.30$ & $71.84 \pm 2.95$ & $18.80 \pm 3.22$ & Silt loam \\
\hline & Average & $9.51 \pm 1.81^{x}$ & $74.06 \pm 3.73^{x}$ & $16.35 \pm 4.14^{z}$ & Silt loam \\
\hline \multirow{4}{*}{ Selangor } & Dry & $1.62 \pm 0.66$ & $51.70 \pm 15.80$ & $46.68 \pm 15.88$ & Silt loam \\
\hline & Wet & $2.19 \pm 0.63$ & $52.27 \pm 14.53$ & $45.55 \pm 14.83$ & Silt loam \\
\hline & Intermediate & $2.40 \pm 1.52$ & $49.71 \pm 12.91$ & $47.90 \pm 13.74$ & Sandy loam \\
\hline & Average & $2.07 \pm 1.04^{z}$ & $51.23 \pm 13.99^{y}$ & $46.71 \pm 14.35^{y}$ & Silt loam \\
\hline \multirow{4}{*}{ Kelantan } & Dry & $4.93 \pm 1.78$ & $39.74 \pm 15.26$ & $56.15 \pm 15.55$ & Sandy loam \\
\hline & Wet & $3.30 \pm 2.11$ & $24.69 \pm 16.80$ & $72.02 \pm 18.88$ & Sandy loam \\
\hline & Intermediate & $3.85 \pm 1.85$ & $28.12 \pm 15.95$ & $68.01 \pm 17.82$ & Sandy loam \\
\hline & Average & $4.02 \pm 1.98^{y}$ & $30.85 \pm 16.78^{\mathrm{z}}$ & $65.39 \pm 18.20^{x}$ & Sandy loam \\
\hline
\end{tabular}

${ }^{\mathrm{x}, \mathrm{y}, \mathrm{z}}$ Different letter denotes significant difference amongst locations

The detail results of the soil texture based on consecutive depth showed that different location had different trend. For example, in Selangor, the composition of clay increased going to the deeper segment. The result also showed that the clay in $60-80 \mathrm{~cm}$ significantly higher than $0-20 \mathrm{~cm}$. In Johor, the results for silt and sand showed significantly difference between 0-20 $\mathrm{cm}$ and $60-80 \mathrm{~cm}$. However, in Delta Kelantan, the soil texture showed no significant difference amongst depth (Figure 2). The soil types were identified at the end of the study. At Johor study site, the soil textures were silt loam for all depth. On the other hand, at Selangor study site, the soil types were different between $0-40 \mathrm{~cm}$ and $40-100 \mathrm{~cm}$, sandy loam and silt loam, respectively. At Kelantan, the soil textures were identified as sandy loam except for 60-80 cm (Table 2). 


\section{Soil chemical analysis}

The results showed that there were significantly different in terms of carbon, nitrogen phosphorus and potassium for all locations. The results for carbon and nitrogen were following this order; Johor $>$ Kelantan $>$ Selangor. The result also showed that Selangor has the highest concentration of phosphorus, followed by Johor and Kelantan. For potassium, the result showed a different trend. The potassium concentration in Johor was significantly higher to the other locations. The following order is Johor >Selangor>Kelantan (Table 3). With exception for phosphorus in Johor study site (Table 4), all chemical properties according to consecutive depth were found to be not significant different.

a

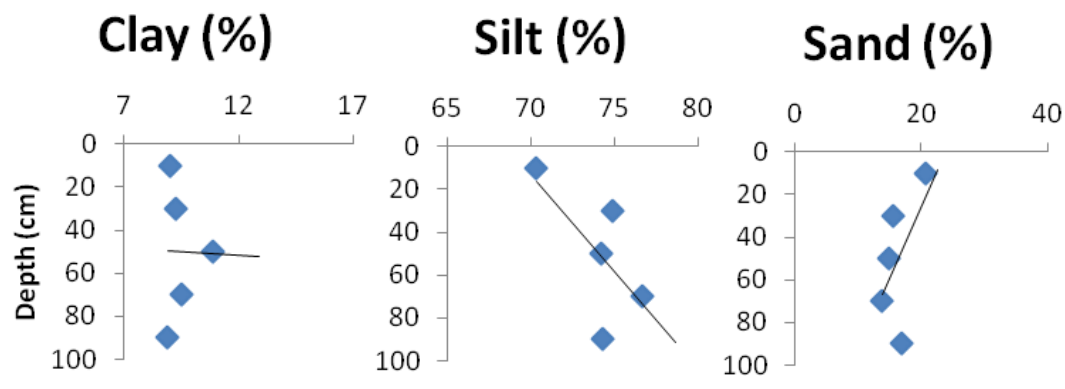

b

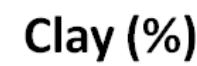

Silt (\%)

Sand

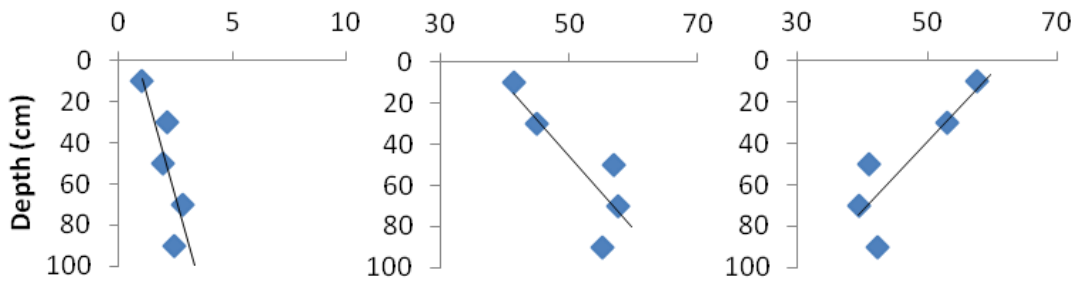

C

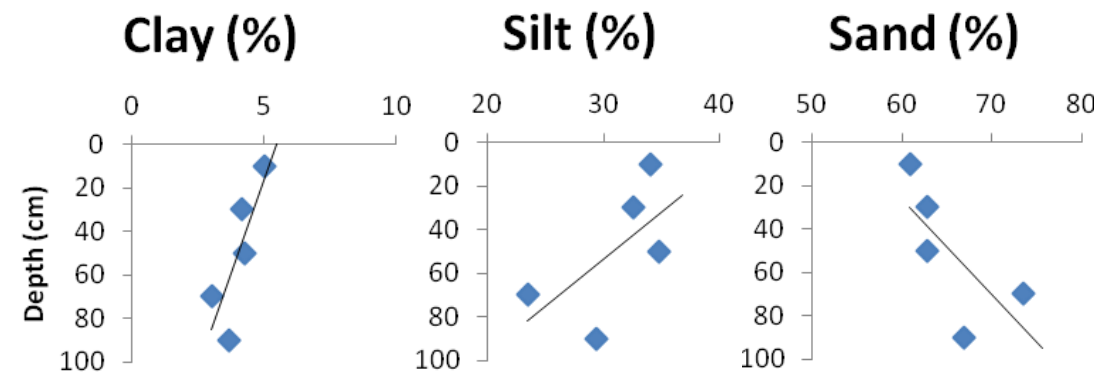

Figure 2. Soil textures according to consecutive depth (a: Johor; b: Selangor; c: Kelantan)

Table 2. Soil texture based on consecutive depth (mean $\pm S D$ )

\begin{tabular}{c|c|c|c|c|l}
\hline Location & Depth & Clay (\%) & Silt (\%) & Sand (\%) & Soil type \\
\hline & $0-20$ & $8.99 \pm 0.37$ & $70.33 \pm 3.62^{\mathrm{b}}$ & $20.68 \pm 3.66^{\mathrm{a}}$ & Silt loam \\
& $20-40$ & $9.27 \pm 0.62$ & $74.88 \pm 3.22^{\mathrm{ab}}$ & $15.48 \pm 3.16^{\mathrm{ab}}$ & Silt loam \\
\multirow{3}{*}{ Johor } & $40-60$ & $10.87 \pm 3.84$ & $74.15 \pm 2.66^{\mathrm{ab}}$ & $14.92 \pm 3.97^{\mathrm{ab}}$ & Silt loam \\
& $60-80$ & $9.53 \pm 0.55$ & $76.67 \pm 2.64^{\mathrm{a}}$ & $13.80 \pm 2.60^{\mathrm{b}}$ & Silt loam \\
& $80-100$ & $8.90 \pm 0.61$ & $74.24 \pm 4.20^{\mathrm{ab}}$ & $16.87 \pm 4.41^{\mathrm{ab}}$ & Silt loam \\
\hline
\end{tabular}




\begin{tabular}{c|c|c|c|c|c}
\hline \multirow{5}{*}{ Selangor } & $0-20$ & $1.02 \pm 0.36^{\mathrm{b}}$ & $41.36 \pm 7.86$ & $57.63 \pm 7.82$ & Sandy loam \\
& $20-40$ & $2.15 \pm 1.34^{\mathrm{ab}}$ & $44.91 \pm 7.37$ & $52.95 \pm 6.80$ & Sandy loam \\
& $40-60$ & $1.96 \pm 0.48^{\mathrm{ab}}$ & $56.95 \pm 15.79$ & $41.10 \pm 15.95$ & Silt loam \\
& $60-80$ & $2.79 \pm 1.07^{\mathrm{a}}$ & $57.75 \pm 15.16$ & $39.47 \pm 15.48$ & Silt loam \\
& $80-100$ & $2.43 \pm 0.94^{\mathrm{ab}}$ & $55.18 \pm 16.36$ & $42.39 \pm 16.76$ & Silt loam \\
\hline \multirow{5}{*}{ Kelantan } & $0-20$ & $5.01 \pm 1.93$ & $34.11 \pm 11.80$ & $60.88 \pm 13.71$ & Sandy loam \\
& $20-40$ & $4.17 \pm 2.21$ & $32.52 \pm 19.60$ & $62.85 \pm 21.93$ & Sandy loam \\
& $40-60$ & $4.25 \pm 1.83$ & $34.79 \pm 19.76$ & $62.75 \pm 18.95$ & Sandy loam \\
& $60-80$ & $3.01 \pm 1.96$ & $23.46 \pm 17.35$ & $73.53 \pm 19.43$ & Loamy sand \\
& $80-100$ & $3.69 \pm 2.05$ & $29.36 \pm 17.78$ & $66.95 \pm 19.81$ & Sandy loam \\
\hline
\end{tabular}

${ }^{\mathrm{a}, \mathrm{b}}$ Different letter denotes significant difference at different depth

Table 3. Soil chemical properties in different seasons and locations (mean $\pm S D$ )

\begin{tabular}{|c|c|c|c|c|c|}
\hline \multirow{2}{*}{ Site } & \multirow{2}{*}{$\begin{array}{l}\text { Soil depth } \\
\quad \text { (cm) }\end{array}$} & \multicolumn{4}{|c|}{ Soil nutrients } \\
\hline & & Carbon $(\%)$ & Nitrogen $(\%)$ & Phosphorus (ppm) & Potassium $(\mathrm{cmol} / \mathrm{kg})$ \\
\hline \multirow{4}{*}{ Johor } & Dry & $5.18 \pm 3.62$ & $0.27 \pm 0.34$ & $25.74 \pm 6.05$ & $2.83 \pm 0.72^{\mathrm{a}}$ \\
\hline & Wet & $6.91 \pm 3.58$ & $0.20 \pm 0.23$ & $25.24 \pm 6.07$ & $2.01 \pm 1.12^{\mathrm{b}}$ \\
\hline & Intermediate & $6.59 \pm 1.82$ & $0.13 \pm 0.04$ & $25.28 \pm 5.09$ & $2.50 \pm 1.80^{\mathrm{ab}}$ \\
\hline & Average & $6.23 \pm 3.18^{x}$ & $0.20 \pm 0.24^{x}$ & $25.42 \pm 5.69^{y}$ & $2.45 \pm 1.32^{x}$ \\
\hline \multirow{4}{*}{ Selangor } & Dry & $2.15 \pm 1.25^{\mathrm{a}}$ & $0.05 \pm 0.01$ & $38.55 \pm 16.70^{\mathrm{b}}$ & $1.25 \pm 1.22$ \\
\hline & Wet & $1.45 \pm 0.63^{\mathrm{b}}$ & $0.05 \pm 0.04$ & $51.42 \pm 23.57^{\mathrm{a}}$ & $1.22 \pm 0.30$ \\
\hline & Intermediate & $1.32 \pm 0.43^{\mathrm{b}}$ & $0.05 \pm 0.02$ & $31.53 \pm 9.29^{\mathrm{b}}$ & $0.88 \pm 0.34$ \\
\hline & Average & $1.64 \pm 0.91^{\mathrm{z}}$ & $0.05 \pm 0.02^{\mathrm{z}}$ & $40.50 \pm 19.20^{x}$ & $1.12 \pm 0.76^{y}$ \\
\hline \multirow{4}{*}{ Kelantan } & Dry & $5.65 \pm 3.07^{\mathrm{a}}$ & $0.11 \pm 0.047$ & $23.79 \pm 12.90^{\mathrm{a}}$ & $0.10 \pm 0.21$ \\
\hline & Wet & $1.62 \pm 0.69^{\mathrm{b}}$ & $0.10 \pm 0.03$ & $12.89 \pm 5.99^{\mathrm{b}}$ & $0.27 \pm 0.53$ \\
\hline & Intermediate & $5.28 \pm 1.63^{\mathrm{a}}$ & $0.11 \pm 0.03$ & $18.76 \pm 8.27^{\mathrm{a}}$ & $0.21 \pm 0.39$ \\
\hline & Average & $4.18 \pm 2.73^{y}$ & $0.11 \pm 0.04^{y}$ & $18.48 \pm 10.40^{z}$ & $0.20 \pm 0.40^{z}$ \\
\hline
\end{tabular}

${ }^{\mathrm{a}, \mathrm{b}}$ Different letter denotes significant difference amongst seasons for each location

${ }^{\mathrm{x}, \mathrm{y}, \mathrm{z}}$ Different letter denotes significant difference amongst locations

Table 4. Soil nutrients at different location according to consecutive depth (mean $\pm S D$ )

\begin{tabular}{c|c|c|c|c|c}
\hline \multirow{3}{*}{ Site } & \multirow{2}{*}{$\begin{array}{c}\text { Soil depth } \\
(\mathbf{c m})\end{array}$} & Carbon (\%) & Nitrogen (\%) & $\begin{array}{c}\text { Phosphorus } \\
(\mathbf{p p m})\end{array}$ & $\begin{array}{c}\text { Potassium } \\
(\mathbf{c m o l} / \mathbf{k g})\end{array}$ \\
\cline { 3 - 6 } & & $5.01 \pm 2.75$ & $0.20 \pm 0.12$ & $22.39 \pm 5.49^{\mathrm{c}}$ & $2.34 \pm 1.05$ \\
& $0-20$ & $6.07 \pm 2.71$ & $0.17 \pm 0.05$ & $23.76 \pm 6.46^{\mathrm{bc}}$ & $2.68 \pm 1.03$ \\
\multirow{5}{*}{ Johor } & $20-40$ & $6.97 \pm 4.10$ & $0.29 \pm 0.42$ & $24.70 \pm 4.05^{\mathrm{abc}}$ & $2.24 \pm 1.04$ \\
& $40-60$ & $5.92 \pm 2.14$ & $0.13 \pm 0.03$ & $27.44 \pm 3.96^{\mathrm{ab}}$ & $2.63 \pm 2.26$ \\
& $60-80$ & $7.16 \pm 3.64$ & $0.20 \pm 0.30$ & $28.79 \pm 6.02^{\mathrm{a}}$ & $2.33 \pm 0.82$ \\
\hline \multirow{5}{*}{ Selangor } & $80-100$ & $1.49 \pm 0.34$ & $0.05 \pm 0.02$ & $40.04 \pm 14.97$ & $1.12 \pm 0.61$ \\
& $0-20$ & $1.65 \pm 0.63$ & $0.06 \pm 0.02$ & $40.42 \pm 17.40$ & $1.29 \pm 0.91$ \\
& $20-40$ & $1.79 \pm 1.07$ & $0.05 \pm 0.02$ & $38.39 \pm 23.12$ & $1.11 \pm 0.64$ \\
& $40-60$ & $1.67 \pm 1.15$ & $0.05 \pm 0.03$ & $43.99 \pm 22.14$ & $1.06 \pm 0.62$ \\
& $60-80$ & $1.61 \pm 1.14$ & $0.04 \pm 0.03$ & $39.63 \pm 18.96$ & $1.00 \pm 1.00$ \\
\hline
\end{tabular}




\begin{tabular}{c|c|c|c|c|c}
\hline & $0-20$ & $4.28 \pm 3.58$ & $0.11 \pm 0.03$ & $20.52 \pm 12.70$ & $0.34 \pm 0.54$ \\
& $20-40$ & $4.07 \pm 2.73$ & $0.11 \pm 0.03$ & $21.04 \pm 9.47$ & $0.21 \pm 0.50$ \\
Kelantan & $40-60$ & $3.79 \pm 2.09$ & $0.10 \pm 0.02$ & $18.92 \pm 8.81$ & $0.14 \pm 0.34$ \\
& $60-80$ & $4.16 \pm 2.26$ & $0.10 \pm 0.20$ & $15.16 \pm 10.21$ & $0.01 \pm 0.11$ \\
& $80-100$ & $4.61 \pm 2.95$ & $0.12 \pm 0.05$ & $16.76 \pm 10.35$ & $0.27 \pm 0.33$ \\
\hline
\end{tabular}

${ }^{\mathrm{a}, \mathrm{b}, \mathrm{c}}$ Different letter denotes significant difference at different depth

\section{Discussion}

The mangrove soil or sediment condition and properties are very important in maintaining the integrity of mangrove ecosystem so that it can fully functioning while providing services to mankind and environment. A sound physical and chemical qualities would ensure that mangrove forest can thrive well despite of worldwide's physically challenging pressure on mangrove land. Malaysia is blessed with $60 \%$ of forested mangroves which includes some areas that have been gazette as Permanent Reserve Forest (PRFs) and declared as Ramsar sites (Jusoff, 2013; Wong, 2004).

The $\mathrm{pH}$ value in Selangor and Kelantan was slightly acidic compared to Johor site. But those values which range from 6.5 to 9.0 are still within the suitable range for marine ecosystem (Robertson and Alongi, 1992). Similarly, the salinity values were within the range for mangrove to grow in healthy condition (Kathiresan and Bingham, 2001). Although the salinity level in Selangor was the highest compared to Kelantan and Johor site. According to Nandy et al. (2007), mangrove species that face tidal inundation daily or twice a month may tolerate extreme $\mathrm{pH}$ and high salinity. The site on Carey Island recorded high salinity 20-26 ppm. Carey Island experience daily tide range varies from 1.5 to $2.5 \mathrm{~m}$ and spring tides and neap tides occur twice a month. The site is exposed to high energy wind and currents, and shipping activities at the nearby Port Klang, whereby the current flow can go up to 70cm/s (Rizal et al., 2010; Sakmani et al., 2013). These winds generate waves with heights of 0.1 to $1.5 \mathrm{~m}$ on the coasts of Carey Island with wave periods of 2 8 s (Muzathik et al., 2011). Kelantan showed very low salinity value, $11 \mathrm{ppm}$ due to its deltaic settings. Johor site also recorded a low value with 14-16 ppm. Its location within a small and narrow Straits of Johor might impending a high salinity influence from the seawater.

Determination of the physical characteristics of the soil texture is important to further explain its ability to retain soil nutrients in the targeted area. Silt and clay particles are finer than sand and have a higher ability to trap nutrients (Ashman and Puri 2002; Kamaruzzaman et al., 2004; Nguyen et al., 2013). In our study, Johor study site recorded a finer soil particle compared to Kelantan and Selangor, with higher percentage of silt and clay compared and therefore, it is expected to retain more nutrients.

The sedimentation refers to the deposition of inorganic or organic matter onto the soil surface in two condition; allochthonous and autochthonous. Kristensen et al. (2008) explained allochthonous is the material derived from outside the mangrove area. For example, Sundarbans mangrove area received over billions of tonnes of sediment from Ganges-Brahmaputra River. Autochthonous refers to the material derived within the mangroves area such as leaf litter, dead trunks and branches, and roots (Cahoon et al., 2003; McKee, 2011). Delta Kelantan receive sediment from few large tributaries rivers that running down to the delta. Carey Island and Johor mainly receive sediment from within its mangrove forest. 
Furthermore, soil physical characteristics also influence primary soil nutrients such as carbon (C), nitrogen (N), phosphorus (P), and potassium (K) (Havlin et al., 2014). Many mangrove sediments have extremely low nutrient availability and high salinity, although they can vary greatly among and within mangrove forests (Reef et al., 2010). In contrast to most terrestrial soils, the flooded soils greatly restrain nitrification, the microbial formation of NO3, which would result in a low nutrient bioavailability in the intertidal sediments ( $\mathrm{Li}$ et al., 2008). N deficiency (Feller et al., 2002, b; Reef et al., 2010) and salinity (Wakushima et al., 1994) have repeatedly been found to be important factors limiting mangrove productivity. Cheng et al. (2012) discovered that a moderate salinity could delay the entry of metals into the roots and thereby contributed to a higher metal tolerance.

The soil nutrients at Johor study site showed the highest concentration; i.e. CNK. But, for P, the value was lower than in Selangor. The soil results also showed a high concentration of nutrients in the bottom soil. This is followed what Havlin et al. (2014) discovered that more nutrients were concentrated in deep soil as a result of plants with extensive roots system, where the roots act as conduits for nutrients from the surface. Without any vegetation, nutrients were concentrated near the surface as a result of natural phenomena like weathering and atmospheric pressure (Jobbagy and Jackson 2001). A high concentration of nutrients, especially in the bottom soil, is very important so that they can be absorbed effectively by higher plants that have extensive root systems (Reef et al., 2010).

Mangroves also known as carbon-rich ecosystems that provide dumping pools for carbon from the atmosphere, allocthonous riverine, ocean elements and authochthonous organisms mechanism (Steven et al., 2004). C concentration was highest in the Johor and Kelantan sites, where those areas were not really affected by agriculture activities, unlike in Carey Island. According to Havlin et al. (2014), C is a fundamental element in mangroves as it promotes biological and physical health and protects from harmful elements. $\mathrm{C}$ concentration in the soil is largely determined by the volume of organic carbon as it is required in large amounts and can be obtained predominantly from the atmosphere. Soil organic carbon (SOC) is affected by both biotic and abiotic activities (Hopkins and Huner, 2004).

In this study, $\mathrm{N}$ also was highly concentrated at Johor and Kelantan. This is important because deficiency in $\mathrm{N}$ could result in soil infertility (Havlin et al., 2014). In soil, the ranges of $\mathrm{N}$ are about average of $0.05 \%$ and the concentrations decrease with soil depth (Havlin et al., 2014). In our study, the $\mathrm{N}$ concentration at Selangor had the minimal effect to the mangroves growth. Some mangrove plants can accumulate the $\mathrm{N}$ through atmospheric nitrogen fixation or symbiotic bacteria present on or in the plants (Reef et al., 2010). The ammonium concentration is higher in muddy areas with high clay and silt composition compared to sandy soil (Alongi et al., 2013). Ashman and Puri (2002) described that the small particles such as silt have the stronger ability to retain $\mathrm{N}$ compared to sandy soil.

The $\mathrm{P}$ concentration was recorded high at Pulau Carey, Selangor. This is might be due to a small river running within Carey Island and receives sediments from the existing oil palm plantation activities as well as rainfall. The standard amount of $\mathrm{P}$ in soil must be within the range of 30-50 ppm (Havlin et al., 2014). For Johor and Kelantan, the values were below the minimum range. Potassium has also been used in fertilizer to increase soil fertility and acts as an indicator of healthy plants (Ashman and Puri, 2002; Havlin et al., 2014). The lack of $K$ value in soil could lead to unhealthy plant growth. $K$ is usually more abundant in silt or clay soil (Reef et al., 2010). 
The current study found the amount of $\mathrm{K}$ was highly at Johor, followed by Selangor and Kelantan. At Kelantan study site, the value of $\mathrm{K}$ was within the range from very low to high concentration. The maximum values for $\mathrm{K}$ in soil should not less than 0.41 $\mathrm{cmol} / \mathrm{kg}$ (Havlin et al., 2014).

Johor is expected to retain higher nutrient since this area was not really disturbed from anthropogenic activities, being gazetted under the Ramsar Site Treaty. This action is a very sound and exemplary of retaining mangrove forest so that little or none disturbance can be expected towards this site. And in turn, the mangroves forest at Tanjung Piai and Pulau Kukup were declared as Johor's State Park and proven that conservation status could well retain the quality and quantity of mangrove forest (Jusoff and Taha, 2008). Mangrove species differ in their growth-response to salinity. Our study sites recorded a reasonable value of salinity, as Patel et al. (2010) suggested that in extreme saline habitats $\mathrm{N}, \mathrm{P}, \mathrm{K}, \mathrm{Ca}$ and $\mathrm{Mg}$ can be limiting factors for the growth of A. marina.

\section{Conclusion}

The soil in Johor and Selangor are dominated by silty loam while Kelantan soil is dominated by sandy loam. Nevertheless, the soil texture in these three study sites indicate stability in soil physical properties since there are no changes across seasons. In term of soil nutrient properties, the protected mangrove area in Johor has higher carbon, nitrogen and potassium compared to other sites. On the other hand, phosphorus concentration in Selangor soil is the highest which might be due to the run-off from oil palm agriculture site. Generally, there are no changes of nutrient concentrations across seasons except for carbon which is much higher in dry season in Selangor and Kelantan, while phosphorus level in Selangor is higher in wet season. Based on the depth, the nutrients are stable since there are no changes for all parameters except for phosphorus in Johor where it was found that the phosphorus was significantly higher in deeper soil.

The finding of this study indicates that the different mangrove habitats according to the land use types yielded different results in soil texture and nutrient composition. The protected mangrove habitat in Johor has siltier and clayey component which in turn can retain more nutrients for the plant growth. This finding proved that conservation and protection of mangrove habitats are needed to maintain the ecosystem services and functions for the well-being of mankind.

Acknowledgements. The authors wish to express their gratitude for the financial support provided by University of Malaya under the grant RP019D-16SUS. We acknowledged the support from the Institute of Biological Sciences, Institute of Ocean and Earth Sciences and Sime Darby Plantations. Permission and assistance from Kelantan Forestry Department and Johor Parks Corporation in conducting the study is greatly appreciated.

\section{REFERENCES}

[1] Alongi, D. M., Clough, B. F., Dixon, P., Tirendi, F. (2003): Nutrient partitioning and storage in arid-zone forests of the mangroves Rhizophora stylosa and Avicennia marina.Trees 17(1): 51-60.

[2] Alongi, D. M., Boto, K. G., Robertson, A. I. (2013): Nitrogen and Phosphorus Cycles Tropical Mangrove Ecosystems (pp. 251-292): - American Geophysical Union, Washington. 
[3] Alongi, D. M. (2014): Carbon cycling and storage in mangrove forests. - Annual Review of Marine Science 6(1): 195-219.

[4] An, S., Li, H., Guan, B., Zhou, C., Wang, Z., Deng, Z., Zhi, Y., Liu, Y., Xu, C., Fang, S., Jiang, J., Li, H. (2007): China's natural wetlands: past problems, current status, and future challenges. AMBIO: - A Journal of the Human Environment 36(4): 335-342.

[5] Ashman, M. R., Puri, G. (2002): Essential Soil Science: A clear and concise introduction to soil science. - Wiley Blackwell Science, Oxford.

[6] Azrina, M. Z., Yap, C. K., Rahim Ismail, A., Ismail, A., Tan, S. G. (2006): Anthropogenic impacts on the distribution and biodiversity of benthic macroinvertebrates and water quality of the Langat River, Peninsular Malaysia. - Ecotoxicology and Environmental Safety 64(3): 337-47.

[7] Binkley, D., Fisher, R. (2012): Ecology and management of forest soils. John Wiley \& Sons, London.

[8] Bosire, J. O., Dahdouh-Guebas, F., Walton, M., Crona, B. I., Lewis III, R. R., Field, C., Kairo, J. G., Koedam, N. (2008): Functionality of restored mangroves: A review. Aquatic Botany 89(2): 251-9.

[9] Cahoon, D. R., Hensel, P., Rybczyk, J., McKee, K. L., Proffitt, C. E., Perez, B. C. (2003): Mass tree mortality leads to mangrove peat collapse at Bay Islands, Honduras after Hurricane Mitch. - Journal of Ecology 91(6): 1093-1105.

[10] Cannicci, S., Burrows, D., Fratini, S., Smith Iii, T. J., Offenberg, J., Dahdouh-Guebas, F. (2008): Faunal impact on vegetation structure and ecosystem function in mangrove forests: A review. - Aquatic Botany 89(2): 186-200.

[11] Chen, R., Twilley, R. (1999): A simulation model of organic matter and nutrient accumulation in mangrove wetland soils. - Biogeochemistry 44(1): 93-118.

[12] Cheng, H., Wang, Y.-S., Ye, Z.-H., Chen, D.-T., Wang, Y.-T., Peng, Y.-L., Wang, L.-Y. (2012): Influence of $\mathrm{N}$ deficiency and salinity on metal ( $\mathrm{Pb}, \mathrm{Zn}$ and $\mathrm{Cu}$ ) accumulation and tolerance by Rhizophora stylosa in relation to root anatomy and permeability. Environmental Pollution 164: 110-117.

[13] Chong, V. C. (2007): Mangroves-fisheries Linkages - the Malaysian perspective. Bulletin of Marine Science 80(3): 755-772.

[14] Das, S., De, M., Ganguly, D., Maiti, T. K., Mukherjee, A., Jana, T. K., De, T. K. (2012): Depth integrated microbial community and physico-chemical properties in mangrove soil of Sundarban, India. - Advances in Microbiology 2: 234-240.

[15] De Vos, B., Lettens, S., Muys, B., Deckers, J. A. (2007): Walkley-Black analysis of forest soil organic carbon: recovery, limitations and uncertainty. - Soil Use and Management 23(3): 221-9.

[16] Duke, N., Lo, E., Sun, M. (2002): Global distribution and genetic discontinuities of mangroves - emerging patterns in the evolution of Rhizophora. - Trees 16(2-3): 65-79.

[17] Feller, I., McKee, K., Whigham, D., O'Neill, J. (2002): Nitrogen vs. phosphorus limitation across an ecotonal gradient in a mangrove forest. - Biogeochemistry 62(2): 145-175.

[18] Furukawa, K., Wolanski E. (1996): Sedimentation in mangrove forests. - Mangroves and Salt Marshes 1(1): 3-10.

[19] Giri, C., Ochieng, E., Tieszen, L. L., Zhu, Z., Singh, A., Loveland, T. Masek, J., Duke, N. (2011): Status and distribution of mangrove forests of the world using earth observation satellite data. - Global Ecology and Biogeography 20(1): 154-9.

[20] Greger, M. (2004): Metal Availability, Uptake, Transport and Accumulation in Plants. In: Prasad, M. N. V. (ed.) Heavy Metal Stress in Plants From Biomolecules to Ecosystems ( $2^{\text {nd }}$ ed., pp. 1-27). - Springer-Verlag, Berlin, Heidelberg.

[21] Gruber, N., Galloway, J. N. (2008): An Earth-system perspective of the global nitrogen cycle. - Nature 451(7176): 293-296.

[22] Havlin, J. L., Tisdale, S. L., Nelson, W. L., Beaton, J. D. (2014): Soil Fertility and Fertilizers: An Introduction to Nutrient Management. - Pearson, Upper Saddle River, NJ. 
[23] Hemati, Z., Hossain, M., Emenike, C. U., Rozainah, M. Z. (2015): Rate of carbon storage in soil of natural and degraded mangrove forest in Peninsular Malaysia. - CLEAN - Soil Air Water 43(4): 614-9.

[24] Hogarth, P. J. (2015): The Biology of Mangroves and Seagrasses (Biology of Habitats Series). $3^{\text {rd }}$ edition. - Oxford University Press, Oxford

[25] Hopkins, W. G., Huner, N. P. A. (2004): Introduction to Plant Physiology ( $3^{\text {rd }}$ ed.). - John Wiley \& Sons, Inc, Hoboken, NJ.

[26] Ibrahim, S., Hussain, M. L. (2012): Mangroves of Terengganu. - University Malaysia Terengganu, Terengganu.

[27] Jobbágy, E., Jackson, R. (2001): The distribution of soil nutrients with depth: Global patterns and the imprint of plants. - Biogeochemistry 53(1):51-77.

[28] Jusoff, K., Taha, D. (2008): Managing sustainable mangrove forest in Peninsular Malaysia. - Journal of Sustainable Development 1(1): 88-96.

[29] Jusoff, K. (2013): Malaysian mangrove forests and their significance to the coastal marine environment. - Polish Journal of Environmental Studies 22(4):979-1005.

[30] Kamali, B., Hashim, R. (2011): Mangrove restoration without planting. - Ecological Engineering 37(2): 387-391.

[31] Kamaruzzaman, Y., Ong, M. C., Willison, K. Y. S. (2004): Trace metal concentration in the surface sediments of Paka mangrove forest, Terengganu, Malaysia. - Malaysian Journal of Science 23(2):55-60.

[32] Kathiresan, K., Bingham, B. L. (2001): Biology of mangroves and mangrove ecosystems. - Advances in Marine Biology 40: 81-251.

[33] Kristensen, E., Bouillon, S., Dittmar, T., Marchand, C. (2008): Organic carbon dynamics in mangrove ecosystems: A review. - Aquatic Botany 89(2): 201-219.

[34] Lewis, R. R. (2005): Ecological engineering for successful management and restoration of mangrove forests. - Ecological Engineering 24(4): 403-418.

[35] Li, Y. L., Fan, X. R., Shen, Q. R. (2008): The relationship between rhizosphere nitrification and nitrogen-use efficiency in rice plants. - Plant, Cell \& Environment 31(1): 73-85.

[36] Malaysian Meteorology Department (MMD) (2010a): General climate of Malaysia. Malaysian Meteorological Department.

[37] Malaysian Meteorology Department (MMD) (2010b): Mean maximum temperature trends of Peninsula: - Malaysian Meteorological Department.

[38] Matthijs, S., Tack, J., van Speybroeck, D., Koedam, N. (1999): Mangrove species zonation and soil redox state, sulphide concentration and salinity in Gazi Bay (Kenya), a preliminary study. - Mangroves and Salt Marshes 3(4): 243-249.

[39] McKee, K. L. (2011): Biophysical controls on accretion and elevation change in Caribbean mangrove ecosystems. - Estuarine, Coastal and Shelf Science 91(4): 475-483.

[40] Muzathik, A. M., Wan Nik, W. B., Samo, K. B., Ibrahim, M. Z. (2011): Ocean wave measurement and wave climate prediction of Peninsular Malaysia. - Journal of Physical Science 22(1): 77-92.

[41] Nandy, P., Das, S., Ghose, M., Spooner-Hart, R. (2007): Effects of salinity on photosynthesis, leaf anatomy, ion accumulation and photosynthetic nitrogen use efficiency in five Indian mangroves. - Wetlands Ecology and Management 15(4): 347357.

[42] Nelson, D. W, Sommers, L. (1980): Total nitrogen analysis of soil and plant tissues. Journal of the Association of Official Analytical Chemists 63: 770-778.

[43] Ngole-Jeme, V. M., Fonge, B. A., Tabot, P. T., Mumbang, C. (2016): Impact of logging activities in a tropical mangrove on ecosystem diversity and sediment heavy metal concentrations. - Journal of Coastal Conservation 20(3): 245-255.

[44] Nguyen, H., Cao, D., Schmitt, K. (2013): Soil particle-size composition and coastal erosion and accretion study in Soc Trang mangrove forests. - Journal of Coastal Conservation 17(1):93-104. 
[45] Nordatul Akmar, Z., Wan Juliana, W. (2012): Reproductive phenology of two Rhizophora species in Sungai Pulai forest reserve, Johor, Malaysia. - Malaysian Applied Biology 41(1): 11-21.

[46] Patel, N. T., Gupta, A., Pandey, A. N. (2010): Salinity tolerance of Avicennia marina (Forssk.) Vierh. from Gujarat coasts of India. - Aquatic Botany 93(1): 9-16.

[47] Rambok, E., Gandaseca, S., Ahmed, O. H., Nik Muhamad, A. M. (2010): Comparison of selected soil chemical properties of two different mangrove forests in Sarawak. American Journal of Environmental Sciences 6(5): 438-441.

[48] Reef, R., Feller, I. C., Lovelock, C. E. (2010): Nutrition of mangroves. - Tree Physiology 30(9):1148-60.

[49] Rizal, S., Iskandar, I., Ilhamsyah, Y., Wahid, M. A., Musman, M. (2010): Currents simulation in the Malacca Straits by using three-dimensional numerical model. - Sains Malaysiana 39(4): 519-524.

[50] Robertson, A. I., Alongi, D. M. (1992): Tropical mangrove ecosystems. - Coastal and estuarine studies 41: 1-330.

[51] Ross, D. S. (1995): Recommended methods for determining soil cation exchange capacity. Recommended soil testing procedures for the northeastern United States. Northeastern Regional Publication (493):62-9.

[52] Rozainah, M. Z., Irfan, I. (2017): Mangrove Flora of Carey Island, Peninsular Malaysia. Proceedings of the Klang Islands Seminar: Discovering Biodiversity \& Sustaining Socioeconomic Benefits. (Eds: Aishah Salleh, Noorma Wati Haron, Shahrakbah Yaacob, Amy Then \& Moh Heng Hing). University of Malaya, Kuala Lumpur.

[53] Sakmani, A. S., Lam, W.-H., Hashim, R., Chong, H.-Y. (2013): Site selection for tidal turbine installation in the Strait of Malacca. - Renewable and Sustainable Energy Reviews 21(0): 590-602.

[54] Salmo, S. G., Lovelock, C., Duke, N. C. (2013): Vegetation and soil characteristics as indicators of restoration trajectories in restored mangroves. - Hydrobiologia 720(1): 1-18.

[55] Salmo, S. G., Lovelock, C. E., Duke, N. C. (2014): Assessment of vegetation and soil conditions in restored mangroves interrupted by severe tropical typhoon 'Chan-hom' in the Philippines. - Hydrobiologia 733(1): 85-102.

[56] Spalding, M., Kainuma, M., Collins, L. (2010): World Atlas of Mangroves. - Earthscan, London.

[57] Saraswathy, R., Rozainah, M. Z., Redzwan, G. (2009): Diversity and biomass estimation of mangrove trees on Carey Island, Malaysia. - Ecology Environment \& Conservation 15(2): 205-11.

[58] Sastranegara, M. H. (2004): The impact of forest use on the intertidal crab community in managed mangroves of Cilacap, Central Java, Indonesia. - Cuvillier Verlag, Göttingen.

[59] Satyanarayana, B., Idris Indra, F., Mohamad Khairul, A., Husain Mohd, L., Shazili Noor, A. M., Dahdouh-Guebas, F. (2010): Mangrove species distribution and abundance in relation to local environmental settings: a case-study at Tumpat, Kelantan Delta, east coast of peninsular Malaysia. - Botanica Marina 53: 79-88.

[60] Sherman, E. R., Fahey, J. T., Martinez, P. (2003): Spatial patterns of biomass and aboveground net primary productivity in a mangrove ecosystem in the Dominican Republic. - Ecosystems 6(4): 384-398.

[61] Steven, B., Tom, M., Inge, O., Nico, K., Frank, D. (2004): Resource utilization patterns of epifauna from mangrove forests with contrasting inputs of local versus imported organic matter. - Marine Ecology Progress Series 278: 77-88.

[62] Tajul Baharuddin, M., Taib, S., Hashim, R., Abidin, M., Rahman, N. (2013): Assessment of seawater intrusion to the agricultural sustainability at the coastal area of Carey Island, Selangor, Malaysia. - Arabian Journal of Geosciences 6(10): 3909-3928.

[63] Tan, D. D., Juliana, W. W., Maimon, A. (2012): Community structure and productivity of mangrove forests in two national parks of West Malaysia. - Malaysian Forester 75(2): $165-176$. 
[64] Twilley, R. R., Chen, R. (1998): A water budget and hydrology model of a basin mangrove forest in Rookery Bay, Florida. - Marine and Freshwater Research 49(4): 309323.

[65] Twilley, R. R., Day, J. W. (2012): Mangrove Wetlands. In: Estuarine Ecology (pp. 165202). - John Wiley \& Sons, Inc, New Jersey.

[66] Vilarrúbia, T. V. (2000): Zonation pattern of an isolated mangrove community at Playa Medina, Venezuela. - Wetlands Ecology and Management 8(1): 9-17.

[67] Wakushima, S., Kuraishi, S., Sakurai, N. (1994): Soil salinity and pH in Japanese mangrove forests and growth of cultivated mangrove plants in different soil conditions. Journal of Plant Research 107(1) 39-46.

[68] Walters, B. B., Rönnbäck, P., Kovacs, J. M., Crona, B., Hussain, S. A., Badola, R., Primavera, J. H., Barbier, E., Dahdouh-Guebas, F. (2008): Ethnobiology, socioeconomics and management of mangrove forests: A review. - Aquatic Botany 89(2): 220-236.

[69] Wong, S. L. (2004): Matang Mangroves. A Century of Sustainable Management. Sasyaz Holdings Sdn. Bhd., Kuala Lumpur. 